\title{
FACTORS THAT RELATED TO THE BASIS OF INFANT IMMUNIZATION SUCCESS AT PEKAUMAN HEALTH CENTER IN BANJARMASIN IN 2015
}

Dwi Rahmawati ${ }^{*}$,

${ }^{1}$ STIKES Sari Mulia, Banjarmasin Indonesia

dwislamet21@gmail.com

Sukamto $^{2}$

${ }^{2}$ Health Department of South Kalimantan

sukamto.67_bjm@yahoo.com

Listia Fitriana $^{1}$

${ }^{1}$ STIKES Sari Mulia, Banjarmasin Indonesia

listia.fitriana09@gmail.com

\begin{abstract}
Objectives: To determine the factors that related to the success of Basic Immunization in Infants in Puskesmas Pekauman Banjarmasin 2015

Method: Cross sectional study approach. The population are all the mothers who bring their babies 9 -12 months to get immunization in Pekauman Health Center. Purposive sampling techniques, sample number 48 people. Bivariate analysis is using fisher exact test $(\alpha=0.05)$, and multivariate is using logistic regression test.

Results: Most respondents have good knowledge, that is 30 people $(62.5 \%)$, the last educational background is basic education and secondary as much as 40 people (83.3\%), more does not work, as many as 31 people (64.6\%), has Good family support is 30 people (62.5\%). There is no relationship between knowledge, education, employment and family support with the success of primary immunization in infants $(p=0.082>0.05 \alpha),(p=0.878>0.05 \alpha),(p=0.051>0.05 \alpha)$, $(\mathrm{p}=0.136>\alpha 0.05)$.
\end{abstract}

Conclusion: There is no relationship between knowledge, education, employment, and family support on the success of basic immunization in infants at Pekauman Health Center.

Keywords: Basic Immunization success, Cross sectional, Factors, Infant

\section{INTRODUCTION}

Immunization is a proven way to control and eliminate life-threatening infectious diseases and is estimated to prevent between two and three million deaths annually [1].

The success of immunization conducted by the government has been progressing from year to year. Several factors that influence the success of immunization are the condition of children under five, the distance to the immunization site, the mother's work, the mother's general, the mother's education, the social and economic status, the immunization counseling from the health officer and the cadre and the mother's 
knowledge about the immunization program [2].

Based on data - data that I get from the health service south kalimantan have started to enter the target achievement of immunization is quite increased compared to previous years. From data of banjarmasin health office that 26 puskesmas in Banjarmasin have reached target of immunization success. Researchers take puskesmas pekauman banjarmasin in addition to densely populated, immunization targets there enough so that can explore what factors that support immunization to increase its success.

Based on question and answer done to 10 mothers who have babies at puskesmas pekauman. Results of question and answer concluded that the mother took the time to bring her child immunized according to the date determined by health personnel that 3 people $(30 \%)$ said they did not know that the completeness of the immunization. Then 7 people $(70 \%)$ said that they do not understand what immunization because they only want to immunize so that their children are not sick easily. In the end they take the time to immunize without knowing well about the completeness of the immunization.

From the above information can be known to the mother who brought her baby immunized for the prevention of disease in her child so that the mother on time to bring his child to immunize so that his child protected from diseases diseases [3] .

This study was conducted to determine the factors related to the success of basic immunization in infants at Puskesmas Pekauman Banjarmasin [4].

\section{METHODS}

The method used in this research is quantitative method with cross sectional approach. The population in this study were all mothers who brought their babies 9 -12 months who immunized in Pekakes Banjarmasin working area of 48 people. The sample in this study is part of the population. Sampling using purposive sampling method. Technique of collecting data by questionnaire method. Data processing through several steps of data examination, data classification, data processing, and data analysis [5].

In bivariate data analysis used is Fisher exact test with significance value $\alpha$ $=0,05$ and confidence value used is $95 \%$ 


\section{RESULTS}

Based on the results of the research, the following results are obtained:

Table 1 Frequency Distribution of Respondents by Knowledge.

\begin{tabular}{ccc}
\hline Knowledge & Frequency & Persentase \\
\hline Good & 30 & $62.5 \%$ \\
Enough & 18 & $37.5 \%$ \\
\hline Total & 48 & $100 \%$ \\
\hline
\end{tabular}

Table 1 shows that most respondents have good category knowledge, ie 30 people $(62.5 \%)$.

Table 2 Distribution of Respondent Frequency by Education

\begin{tabular}{crr}
\hline Education & Frequency & Persentase \\
\hline $\begin{array}{c}\text { Basic and } \\
\text { Intermediate } \\
\text { (primary } \\
\text { school, Junior } \\
\text { high school }, \\
\text { and Senior } \\
\text { High School) }\end{array}$ & 40 & 83.3 \\
\hline High & & \\
\hline Total & 8 & 16.7 \\
\hline
\end{tabular}

Based on table 2 above can be seen that the education of most respondents is in primary and secondary education that is 40 people $(83.3 \%)$.

Table 3 Frequency Distribution of Respondents by Occupation

\begin{tabular}{ccc}
\hline Work & Frequency & Persentase \\
\hline Work & 70 & 70,7 \\
\hline $\begin{array}{c}\text { Does not } \\
\text { work }\end{array}$ & 29 & 29,3 \\
\hline Total & 99 & 100 \\
\hline
\end{tabular}

Table 3 shows that more respondents did not work, ie 31 people (64.6\%).
Table 4 Distribution of Respondents Frequency based on Family Support

\begin{tabular}{ccc}
\hline $\begin{array}{c}\text { Family } \\
\text { support }\end{array}$ & Frequency & Persentase \\
\hline Good & 30 & $62.5 \%$ \\
\hline Less & 18 & $37.5 \%$ \\
\hline Total & 48 & $100 \%$ \\
\hline
\end{tabular}

Table 4 shows that the respondents with the support of the families with the good category were the most, ie 30 people $(62.5 \%)$. From the results of research conducted on 48 respondents the results obtained as follows: Table 5 Maternal Knowledge Relations with Basic Immunization Success on Toddlers at

Puskesmas Pekauman Banjarmasin

\begin{tabular}{|c|c|c|c|c|c|c|c|}
\hline \multirow[t]{3}{*}{ Knowledge } & \multicolumn{4}{|c|}{$\begin{array}{c}\text { Basic Immunization } \\
\text { of Underfives }\end{array}$} & \multirow{2}{*}{\multicolumn{2}{|c|}{ Total }} & \multirow[t]{3}{*}{$\begin{array}{c}P- \\
\text { Value }\end{array}$} \\
\hline & \multicolumn{2}{|c|}{ Complete } & \multicolumn{2}{|c|}{$\begin{array}{l}\text { Incompl } \\
\text { ete }\end{array}$} & & & \\
\hline & $\mathrm{N}$ & $\%$ & $\mathrm{~N}$ & $\%$ & $\mathrm{~N}$ & $\%$ & \\
\hline Good & $\begin{array}{l}4 \\
5\end{array}$ & $98 \%$ & 1 & $2 \%$ & $\begin{array}{l}4 \\
6\end{array}$ & $\begin{array}{c}100 \\
\%\end{array}$ & 0.082 \\
\hline Enough & 1 & $50 \%$ & 1 & $\begin{array}{l}50 \\
\%\end{array}$ & 2 & $\begin{array}{c}100 \\
\%\end{array}$ & \\
\hline Total & $\begin{array}{l}4 \\
6\end{array}$ & $\begin{array}{c}95.8 \\
\%\end{array}$ & 2 & 4.2 & $\begin{array}{l}4 \\
8\end{array}$ & $\begin{array}{c}100 \\
\%\end{array}$ & \\
\hline
\end{tabular}

Based on table 5 above found that wellinformed mothers and with complete basic immunization in infants are the most, ie 45 people (98\%). From Fisher exact test obtained from $\mathrm{p}$-value $=0.082>\alpha 0.05$ then $\mathrm{H} 0$ accepted means there is no relationship between knowledge with the success of basic immunization in toddlers. 
Table 6 Maternal Education Relationship with the Success of Basic Immunization on Toddlers at Puskesmas Pakauman Banjarmasin

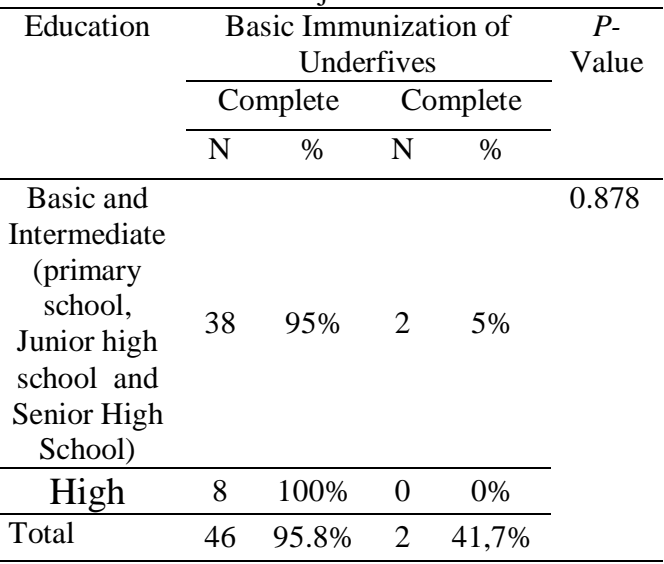

Based on table 6 above, it is found that the first educated mother is the primary and secondary education with complete basic immunization on the toddler is the most that are 38 people (95\%). Fisher exact test results obtained $\mathrm{p}=0.878>\alpha 0.05$ then $\mathrm{H} 0$ accepted means there is no relationship between education with the success of primary immunization in infants.

Table 7 Employment Relations of Mothers with the Success of Basic Immunization of Under-five at Puskesmas Pekauman Banjarmasin

\begin{tabular}{lccccc}
\hline \multirow{2}{*}{ Work } & \multicolumn{3}{c}{$\begin{array}{c}\text { Basic Immunization of } \\
\text { Underfives }\end{array}$} & \multirow{2}{*}{$\begin{array}{c}P- \\
\text { Value }\end{array}$} \\
\cline { 2 - 4 } & \multicolumn{4}{c}{ Complete } & \multicolumn{2}{c}{ Complete } & \\
\cline { 2 - 5 } & $\mathrm{N}$ & $\%$ & $\mathrm{~N}$ & $\%$ & \\
\hline Work & 15 & $88.2 \%$ & 2 & $11.7 \%$ & 0.051 \\
\hline $\begin{array}{l}\text { Does } \\
\text { work }\end{array}$ & 31 & $100 \%$ & 0 & $0 \%$ & \\
\hline Total & 46 & $95.8 \%$ & 2 & $4.2 \%$ & \\
\hline
\end{tabular}

Based on table 7 above, it is known that mothers who do not work with complete basic immunization in Caitanya are the most respondent that is 31 people $(64,9 \%)$. Fisher exact test results $\mathrm{p}=0.051>\alpha 0.05$ then $\mathrm{H} 0$ accepted means there is no relationship between maternal work with the success of primary immunization in infants.

Table 8 Relation of Family Support to the Success of Basic Immunization of Underfives at Puskesmas Pekauman Banjarmasin

\begin{tabular}{|c|c|c|c|c|c|}
\hline \multirow[t]{3}{*}{$\begin{array}{l}\text { Family } \\
\text { support }\end{array}$} & \multicolumn{4}{|c|}{$\begin{array}{c}\text { Basic Immunization of } \\
\text { Underfives }\end{array}$} & \multirow[t]{3}{*}{$\begin{array}{c}P- \\
\text { Value }\end{array}$} \\
\hline & \multicolumn{2}{|c|}{ Complete } & \multicolumn{2}{|c|}{ Complete } & \\
\hline & $\mathrm{N}$ & $\%$ & $\mathrm{~N}$ & $\%$ & \\
\hline Good & 30 & $100 \%$ & 0 & $0 \%$ & 0.136 \\
\hline Less & 16 & $89 \%$ & 2 & $111 \%$ & \\
\hline Total & 46 & $95.8 \%$ & 2 & $4.2 \%$ & \\
\hline
\end{tabular}

Based on table 8 above shows that mothers who with good family support tend to have a complete basic immunization history in their toddler, ie 30 people $(62.5 \%)$. Fisher exact test result value $\mathrm{p}=0.136>\alpha 0.05$ then $\mathrm{H} 0$ accepted means there is no relationship between family support with the success of primary immunization in infants.

\section{DISCUSSION}

Immunization is an important public hea lth interventions strategy to reduce the morbidity and mortality associated with infectious diseases. Over two million deaths are delayed through immunizatio n each year worldwide (WHO, 2003).

Despite this, vaccinepreventable diseases remain the most common cause of childhood mortality with an estimated three million deaths each year (CGD, 200). Upt ake of vaccination services is dependent not onl $y$ on provision of these services but also on othe $\mathrm{r}$ factors including knowledge and attitude of $\mathrm{m}$ others (Matsumura et al, 2005; Torun \& Bakirci 
, 2006), density of health workers (Anand \& Ba rnighusen, 2007), accessibility to vaccination clinics and availability of safe needles and syringes.

Based on the results of the study showed that all the variables studied were not related to the success of immunization. Due to the success of immunization has a lot of factors that must be in further care. Not just knowledge, education, mother work, family support. However, it can also be attributed to the attitude of the mother, the support of the health worker, the distance to the health facility, the social culture, the long queues at the health facility.

This is in line with the study conducted by Abdulraheem et al (2011) on the reasons for the incompleteness of vaccination, the results show that the reasons for the mother not to provide complete immunization include Mother doubts the safety of immunization, distant home distance, long queues at health facilities, and lack of understanding of contraindications to immunization [6].

The finding that female children had a higher likelihood of receiving full immunization is noteworthy and has been

\section{CONCLUSION}

There is no relationship between knowledge, education, mother work, family reported in a few other studies. The reasons for this difference are speculative and require further investigation with qualitative methods; however, much of the evidence indicates that in areas with a strong preference for sons, female children are relatively less likely to be immunized, whilst other studies have found a lower likelihood of immunization for male children [7].

Another study in India explained that there were a significant relationship between mother's education and adoption of child immunization program. The female children had less chance to get immunization than male children in both countries India and Pakistan. The male household heads had .471 less likelihood to immunize their children while the situation was opposite in India where the males had 1.210 more chances to immunize their children compared to the female household heads. In Nepal, found that the male head of family had less likelihood to immunize their children as compared to the female head of the family [8].

support with the success of primary immunization in infants. 


\section{REFERENCES}

[1]. SEARO WHO. Hepatitis B control by 2014 in the WHO Western Pacific Region: rationale and implications. Bulletin of the World Health Organization [online]. $\mathrm{WHO}_{-}$

Hepatitis B control by 2014 in the WHO Western Pacific Region rationale and implications.htm. [Diakses pada tanggal 15 Juli 2015]. 2014.

[2]. Tawi, Mirzal. Immunization and Factors Affecting it. Bandung: Shehadeh

[3]. Ningrum. 2008. Factors Affecting Basic Immunization Completeness in Infants at Banyudono Health Center Boyolali District. News Science of Nursing ISSN 1979-2697, Vol. 1 No.1. 2008.

[4]. Prasetya, Endah, and Sulastri. Factors that affect completeness of basic immunization on baby at Bonyudono Public Health Center Boyolali District. News journal nursing science, Vol.1 No. 1. 2008.

[5]. Notoatmodjo. Public Health Science and Art. Jakarta:

Rineka Cipta 2007.

[6]. Abdulraheem, I.S., Onajole.A.T., Jimoh.A.A.G., Oladipo.A.R., Reason for incomplete vaccination and factors for missed opportunities among rural Nigerian children. Journal of Public Health and Epidemiology Vol.3(4). 2011.

[7]. Antai Diddy. Gender Inequities, relationship power, and Chilhood Immunization Uptake In Nigeria: a population-based cross-sectional study International Journal Of Infectious Diseases 16 (2012) el36-el45

[8]. Subhani Samra, Rizwan Yaseen, Masood Ahmad Khan, Ghulam Jeelani, and Rida Fatima, "Impact of Mother's Education on Child Immunization: A Comparative
Study of India and Pakistan." Journal of Finance and Economics, vol. 3, no. 3: 51-54. doi: 10.12691/jfe-3-3-1. 2015

[9]. Bofarraj, M. Knowledge, Attitude and Practices of Mothers Regarding Immunization of Infants and Preschool Children at Al-Beida City. Libya 2008. Egypt J Pediatr Allergy Immunol 9(1). 2011

[10]. Hanan Abbas Abdo Abdel Rahman EI Gammal. Maternal satisfaction about childhood Immunization in primary healh care center, Egypt Received:24/05/2012.Accepted:04/06/20 13-Published:18/06/2014pan African Medical Journal.2014;18:157doi:10.11604/pamj. 18.157.1773. 2014.

[11].O. Awodele1*, I.A. Oreagba1, A. Akiny ede1, D.F. Awodele2 And D.Dolapo3,T he knowledge, and attitude towards child hood immunization among mothers atten ding the antenatal clinic in Lagos University Tea ching Hospital, Nigeria.

[12]. Sunaryo.. Psychology for Nursing. Jakarta: EGC. 2004

[13].Vincenzo Restivo, Giuseppe Napoli, Maria Grazia Laura Marsala, Valentina Bonanno, Valentina Sciuto, Emanuele Amodio, Giuseppe Calamusa, Francesco Vitale \& Alberto Firenze. Factors associated with poor adherence to MMR vaccination in parents who follow vaccination schedule, Human Vaccines \& Immunotherapeutics, 11:1, 140-145, DOI: 10.4161/ hv.34416. 2015

[14]. Wawan, A and Dewi M. Knowledge, Attitudes and Human Behavior. Yogyakarta: Nuha Medika.2011. 